\title{
Stabilization of soft clayey soils with sawdust ashes
}

\author{
${\text { Hussein } \text { Karim }^{1, *} \text {, Makki Al-Recaby }}^{1}$, and Maha Nsaif $^{1}$ \\ ${ }^{1}$ Building and Construction Engineering Department, University of Technology, Baghdad, Iraq
}

\begin{abstract}
The problems of soft clayey soils are taken in considerations by many Iraqi geologists and civil engineers, because about $35 \%$ of the Iraqi clay soils (especially southern Iraq) are weak. Thus, it is necessary to improve the properties of such soils for road construction by means of using of various stabilizers such as sawdust ash. The main goal of the present study is to stabilize soft clay models with sawdust ash (SDA) additive using different percentages $(0,2,4,6,8$ and $10 \%$ by dry weight of soil). The results revealed that the additive has adverse effects on the property of soil indices by increasing its liquid limit and plasticity index due to clay content. The mixture of sawdust ashes with soft clay soils improves most other physical and mechanical properties of the soil, as expressed by a general reduction in specific gravity and maximum dry density (MDD), as well as a reduction in the compression coefficients $\left(C_{c}\right.$ and $C_{r}$ ) with an increase in SDA content. While increasing the optimum moisture content (OMC) and the undrained shear strength $\left(c_{u}\right)$ with the increase in SDA content. The stabilized soils (with 4 and $10 \%$ ash content) resulted in low CBR values (1.6-1.2\%) which can be used as sub-base. The SDA can be considered as a cheap and acceptable stabilizing agent in road construction for improving most of the geotechnical properties of the soft clayey soil.
\end{abstract}

\section{Introduction}

Soft clay soils are recent alluvial deposits presumably formed through the most recent 10,000 years described by their featureless and flat ground surface. These soils are wide spread in Mesopotamian Plain in Iraq particularly in its southern part which are characterized by their low bearing capacity and strength besides their low California bearing ratio (CBR) [1].

Soft clays are characterized by their low undrained shear strength and high compressibility. Such clays are defined as a disturbed cohesive soil whose water content is higher than its liquid limit, such materials display extremely low yield stresses and represent difficult construction conditions. Thus, such types of clays always bring the problems of soil instability and structure settlement. Therefore, the construction of buildings, road, bridges canals and railway in such problematic clayey soils has always been associated with such problems [1,2].

The designs of earth structures require the knowledge on the behavior and stress-related deformability of soils that will support the structure and the geological conditions of the soil under consideration. Thus, the design should be safe enough against shear failure with reasonable amount of settlement. The geotechnical properties of a soil assessed by proper laboratory or in situ tests are used in predicting the behavior of soil when subjected to loads. However, under certain circumstances, all of the needed parameters cannot be determined or are not determined because of economic or other reasons $[3,4]$.
Stabilization of soft and compressible soils clarifies the different ways of improvement for the natural soil properties either by using additives through mixing the natural soil with a stabilizing material (lime, cement or organic materials such as ashes) to obtain a homogeneous mixture) [1] or by column type techniques (sand or stone columns) or by both i.e. columns mixed with additives [5]. Nowadays, huge byproduct solid materials (wastes) are available like fly ash, rice husk ash, reeds and papyrus ashes which can be used as soil stabilizer instead of costly lime or cement $[6,7]$. There are ongoing research studies concerning the possibility of using other naturally occurring materials such as ashes of agricultural waste products for soil stabilization because of their pozzolanic nature [8]. Saw dust is one of the byproducts from timber industry and wood cutting factories.

The present study investigates whether the sawdust ashes (SDA) can be used as an additive to stabilize soft clayey soils by improving their geotechnical properties which will encourage the use of SDA as a stabilizer for clayey soil to solve road failure problems.

\section{Materials and methodology}

\subsection{Soil used}

Disturbed soil samples used for this study are brought from borrow pits at a depth of 1-1.5 m collected from Al-Maymunah site (Latitude $31^{\circ} 54^{\prime} \mathrm{N}$ and Longitude $47^{\circ} 2^{\prime}$ E) which is located within Maysan Governorate about $393 \mathrm{~km}$ south of Baghdad. Geologically, the 
location is situated within the Mesopotamian basin which is characterized by its recent sediments. Samples were packed in nylon bags. The natural moisture content was determined immediately in the Soil Mechanics Laboratory, University of Technology. After that, the soil samples were spread out in the laboratory for two weeks for air-drying at room temperature to eliminate the natural water which may affect analysis. Then, soils were sieved with sieve No. 4 (4.76 $\mathrm{mm}$ opening) to obtain the final soil samples for the tests. After the drying period, lumps in the samples were slightly pulverized with minimal pressure. Thereafter, soil tests have been conducted for this work applying standard procedures. Grain size distribution of the soils used is shown in Figure 1 while the plasticity chart for the natural soil is illustrated in Figure 2. According to the Unified Soil Classification System (USCS) [9], the soil is classified as CL. Table 1 presents the properties of the natural soft soil used in this investigation.

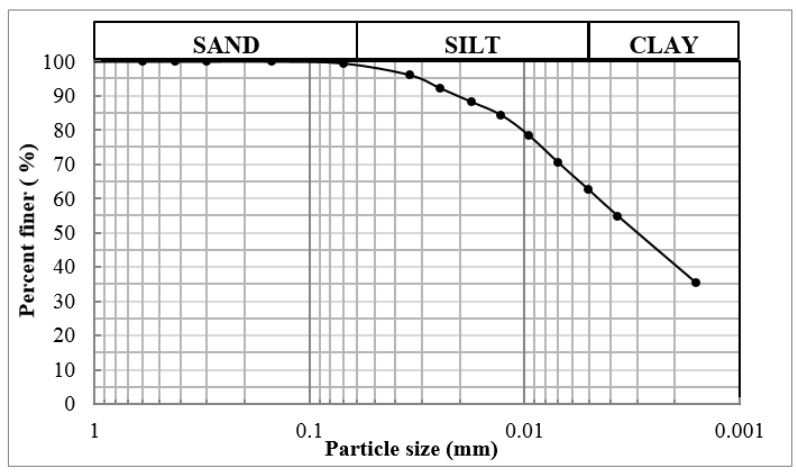

Fig. 1. Grain size distribution curve.

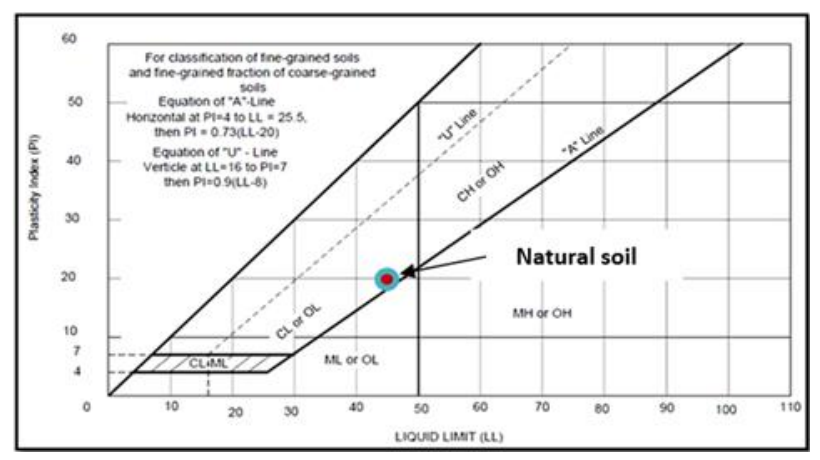

Fig. 2. Plasticity chart for the natural soil.
Table 1. Physical and chemical properties of natural soil used.

\begin{tabular}{|c|c|}
\hline Property & Value \\
\hline Initial water content (W.C) \% & 42 \\
\hline Depth (m) & 1.5 \\
\hline Liquid limit (L.L) (\%) & 45 \\
\hline Plastic limit (P.L) (\%) & 25 \\
\hline Linear shrinkage (L.S) (\%) & 11 \\
\hline Plasticity index (P.I) (\%) & 20 \\
\hline Activity $\left(\mathrm{A}_{\mathrm{t}}\right)$ & 0.50 \\
\hline Specific gravity $\left(\mathrm{G}_{\mathrm{s}}\right)$ & 2.68 \\
\hline Gravel (larger than $2 \mathrm{~mm})(\%)$ & 0 \\
\hline Sand $(0.06$ to $2 \mathrm{~mm})(\%)$ & 0.5 \\
\hline Silt $(0.005$ to 0.06$)(\%)$ & 37.5 \\
\hline Clay (less than $0.005 \mathrm{~mm})(\%)$ & 62 \\
\hline Classification (USCS) & $\mathrm{CL}$ \\
\hline Organic material (O.M) (\%) & 0.925 \\
\hline Calcium oxide $(\mathrm{CaO})(\%)$ & 14.616 \\
\hline $\mathrm{SO}_{3}$ content $(\%)$ & 1.108 \\
\hline Total dissolved salt (TDS) (\%) & 4.91 \\
\hline $\mathrm{pH}$ value & 8.16 \\
\hline $\mathrm{Cl}$ & 1.598 \\
\hline OMC (\%) & 16.87 \\
\hline $\operatorname{MDD}\left(\mathrm{kN} / \mathrm{m}^{3}\right)$ & 18.5 \\
\hline
\end{tabular}

\subsection{Sawdust ashes}

Sawdust ashes are loose particles or wood chippings obtained by sawing hard wood into standard useable sizes and then burned. Clean sawdust without a large amount of bark has proved to be satisfactory because of low organic content. Then, the sawdust was spread on the ground and air dried to facilitate its burning. Sawdust was burnt to ashes and was then sieved through a sieve of $75 \mu \mathrm{m}$ to get very fine ash. After that, the sieved ashes were put in oven at $500^{\circ} \mathrm{C}$ for two hours to ensure removal of any organic matter. Then, it was stored in an air tight container to prevent moisture loss and any form of contamination. Figure 3 shows the burning of sawdust. The chemical composition of sawdust ashes (SDA) are different with various types of wood, but they predominantly comprise silica, alumina and lime [10]. The chemical composition of sawdust used is mainly silica, alumina, and lime besides other oxides with less proportions. The physical properties are tabulated in Table 2.

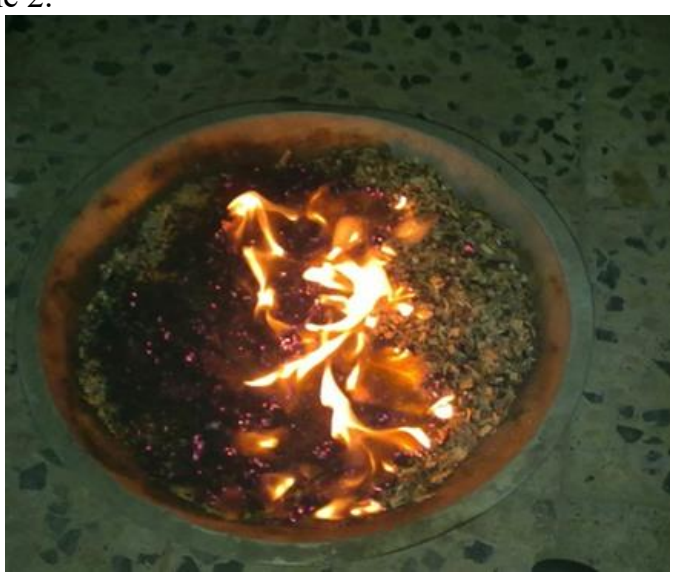


Fig. 3. Burning of sawdust.

Table 2. Physical properties and chemical composition of the used sawdust ash.

\begin{tabular}{|c|c|}
\hline Index Property & Index Value \\
\hline Specific gravity & 2.02 \\
\hline Fineness & $75 \mu \mathrm{m}$ \\
\hline Fineness Silica $\left(\mathrm{SiO}_{2}\right)$ & $76.3 \%$ \\
\hline Alumina $\left(\mathrm{Al}_{2} \mathrm{O}_{3}\right)$ & $5.8 \%$ \\
\hline Lime (Cao) & $4.7 \%$ \\
\hline Iron oxide $\left(\mathrm{Fe}_{2} \mathrm{O}_{3}\right)$ & $2.9 \%$ \\
\hline $\mathrm{SO}_{3}$ & $1.6 \%$ \\
\hline $\mathrm{MgO}$ & $1.2 \%$ \\
\hline Other oxides & $2.5 \%$ \\
\hline Loss in ignition & $3.9 \%$ \\
\hline
\end{tabular}

\subsection{Water}

Ordinary water was used in the experimental work.

\subsection{Preparation of soil mixtures}

The selected percentages of ash were at rates $0,2,4,6$, 8 , and $10 \%$ of the dry weight of the natural untreated soil. The soil-additive mixtures were prepared by thoroughly mixing of dry quantities of soil and predetermined amount of stabilizer (ash) in a mixing tray to obtain a uniform color for a minimum of 5 minutes, and the required amount of distilled water was added to the dry mixtures. The prepared soil-ash mixture samples are then mixed carefully until a homogeneous color was obtained.

\subsection{Experimental tests}

Several experimental tests were made to investigate the soil behavior after adding the sawdust ash. These tests are presented in Table 3. All samples for unconfined compressive strength (UCS), California bearing ratio (CBR) tests, and compressibility tests were performed at the optimum moisture content (OMC) and maximum dry unit weight values of the natural soil.

Table 3. Conducted tests with their standards.

\begin{tabular}{|l|l|l|}
\hline $\begin{array}{l}\text { Item } \\
\text { No. }\end{array}$ & Property & Standard \\
\hline 1 & Specific gravity & ASTM D 854 [11] \\
\hline 2 & Atterberg's limits & ASTM D 4318 [12] \\
\hline 3 & Modified compaction & ASTM D 1557 [13] \\
\hline 4 & UCS $\left(q_{u}\right)$ & ASTM D 2166 [14] \\
\hline 5 & CBR & ASTM D 1883 [15] \\
\hline 6 & Compressibility & ASTM D 2435 [16] \\
\hline
\end{tabular}

\section{Test results and discussion}

Test results with and without addition of SDA are illustrated in Table 4. These results involved the main preliminary tests (such as Atterberg's limits, specific gravity, particle size analysis, maximum dry density, optimum moisture content, CBR, undrained shear strength and consolidation) before and after the addition of SDA.

Table 4. Results of geotechnical properties before and after the addition of sawdust ash.

\begin{tabular}{|c|c|c|c|c|c|c|c|c|c|c|c|}
\hline \multirow{2}{*}{$\begin{array}{c}\text { Added } \\
\text { sawdust } \\
\text { ash } \\
(\%)\end{array}$} & \multirow[t]{2}{*}{$\begin{array}{l}\text { L.L } \\
\text { (\%) }\end{array}$} & \multirow[t]{2}{*}{$\begin{array}{l}\text { P.L } \\
\text { (\%) }\end{array}$} & \multirow[t]{2}{*}{$\begin{array}{l}\text { P.I } \\
(\%)\end{array}$} & \multirow[t]{2}{*}{$\mathbf{G}_{\mathbf{s}}$} & \multirow[t]{2}{*}{$\begin{array}{l}\text { MDD } \\
\left(\mathbf{k N} / \mathbf{m}^{3}\right)\end{array}$} & \multirow[t]{2}{*}{$\begin{array}{c}\text { OMC } \\
(\%)\end{array}$} & \multirow[t]{2}{*}{$\begin{array}{l}\text { CBR } \\
(\%)\end{array}$} & \multirow{2}{*}{$\begin{array}{c}\text { Unconfined } \\
\text { compressive } \\
\text { Strength }\left(q_{u}\right) \\
\left(\mathbf{k N} / \mathbf{m}^{2}\right)\end{array}$} & \multirow{2}{*}{$\begin{array}{l}\text { Undrained } \\
\text { shear } \\
\text { strength }\left(c_{u}\right) \\
\left(\mathbf{k N} / \mathbf{m}^{2}\right)\end{array}$} & \multicolumn{2}{|c|}{$\begin{array}{c}\text { Consolidation } \\
\text { test }\end{array}$} \\
\hline & & & & & & & & & & $C_{c}$ & $C_{r}$ \\
\hline 0 & 45 & 25 & 20 & 2.68 & 16.87 & 18.5 & 4.9 & 39.2 & 19.6 & 0.24 & 0.02 \\
\hline 2 & 50 & 23 & 27 & 2.67 & 16 & 14.2 & - & 38.5 & 19.3 & 0.12 & 0.02 \\
\hline 4 & 52 & 25 & 27 & 2.65 & 15.7 & 20.76 & 1.6 & 169.23 & 84.6 & 0.14 & 0.03 \\
\hline 6 & 40 & 24 & 16 & 2.8 & 15.4 & 17.5 & - & 98.30 & 49.15 & 0.14 & 0.04 \\
\hline 8 & 50 & 27 & 23 & 2.43 & 15.56 & 19.67 & - & 52.43 & 26.2 & 0.11 & 0.03 \\
\hline 10 & 54 & 27 & 27 & 2.85 & 13.9 & 23.61 & 1.2 & 74.92 & 37.5 & 0.10 & 0.03 \\
\hline
\end{tabular}


Based on the specification of maximum liquid limit of $40 \%$ by the Federal Ministry of Works and Housing for soils to be used as sub-grade materials, since the average liquid limits of natural clayey soil samples are higher than $40 \%$, therefore soil under consideration are not suitable for road construction unless they are stabilized.

The consistency limits are indicators of clay behavior. The variation in these limits with SDA content is shown in Fig. 4. As a general trend, the whole consistency limits show increase with increasing SDA content. This behavior is confirmed by Adetoro and Faluyi (2015) [17] and Butt et al. (2016) [7]. This could be due to its higher water absorption affinity (i.e. water needed for hydration). According to Whitlow (1995) [18], liquid limits between 45 and 54\% indicate that the soil has an intermediate plasticity. It can be also noticed from Table 1 that liquid limit and plasticity index values for both untreated and treated soils are above $35 \%$ and $12 \%$ respectively, pointing to the high content of clay. Thus, the addition of SDA makes the soil more plastic. It seems that the additive percentages are still not effective due to the high clay content in the soil. Although the SDA addition of $6 \%$ reduces consistency limits, but the general trend of increase in these limits with SDA addition indicating the stabilization of soil to some extent as SDA additive increases. The plasticity indices of samples decreased from 20 to around 16 at $6 \%$ SDA addition may be considered as indication of soil improvement as this causes a removal of some water that can be absorbed by clay minerals [19].

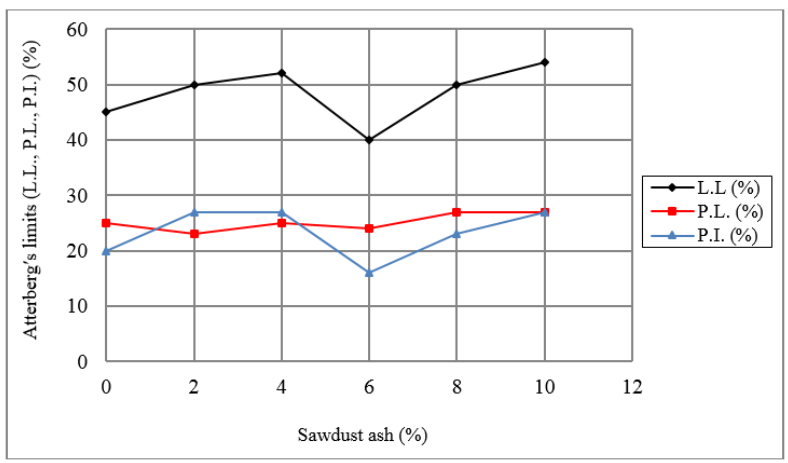

Fig. 4. Liquid limit, plastic limit and plasticity index variation with sawdust ash content.

The specific gravities of natural soil and SDA were 2.68 and 2.02 respectively, while the addition of sawdust ash resulted in the reduction of its specific gravity and its unit weight of soft clay-ash mixtures (around 2.43 at $8 \%$; and 2.65 at 2 and $4 \%$ ) compared to the untreated soft clay soil. This could be considered as an enhancement for the soil property for different geotechnical practices (Figure 5).

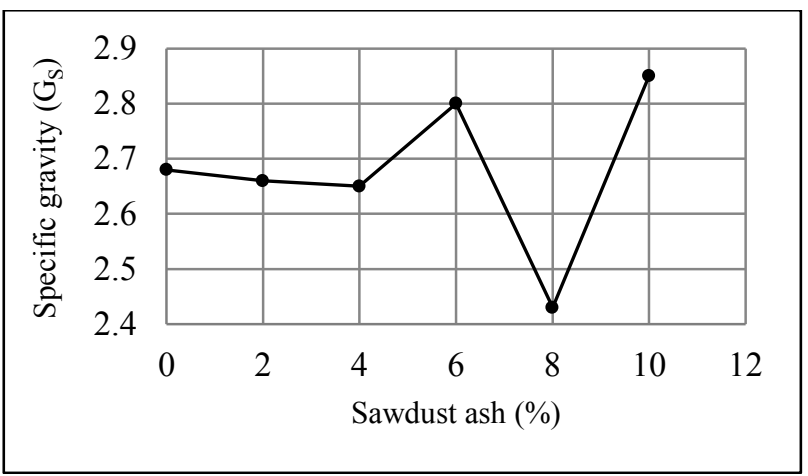

Fig. 5. Relation of specific gravity with percent added of sawdust ash.

The optimum moisture content (OMC) for untreated samples is $18.5 \%$ with maximum dry density (MDD) of $16.87 \mathrm{kN} / \mathrm{m}^{3}$. With an increase in the SDA percent, an increase in $\mathrm{OMC}$ values and a reduction in MDD values were noticed as displayed in Figure 6. The variation in maximum dry density (MDD) and optimum moisture content (OMC) with SDA content (\%) is shown in Figures 7 and 8 respectively. The maximum dry density (MDD) in almost all samples slightly decreases with increasing SDA additive which is related to the addition of fine additive with lower specific gravity with respect to the natural soil. But as a general trend, the optimum moisture content (OMC) exhibits an increase with SDA addition which might be a result of water needed for hydration and compaction of soil-ash mixtures. These findings are in conformance to the results obtained by Henry and Ogunribido (2012) [20] and Butt et al. (2016) [7].

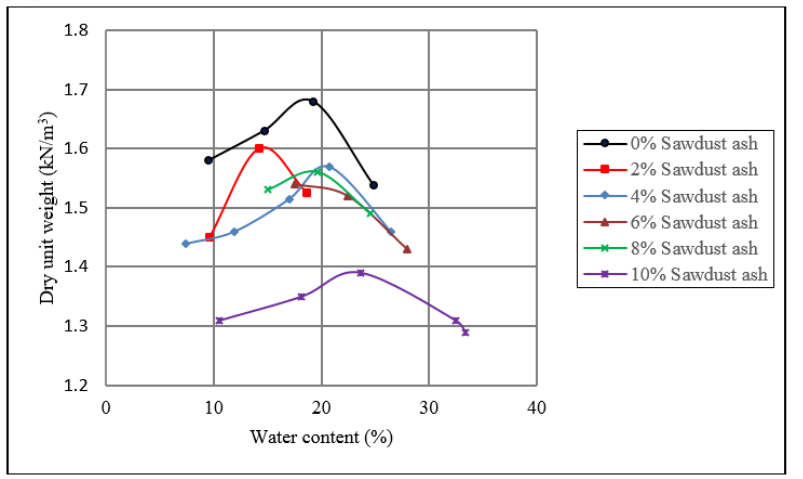

Fig. 6. Optimum moisture content (OMC) obtained from the compaction test for untreated and treated soils.

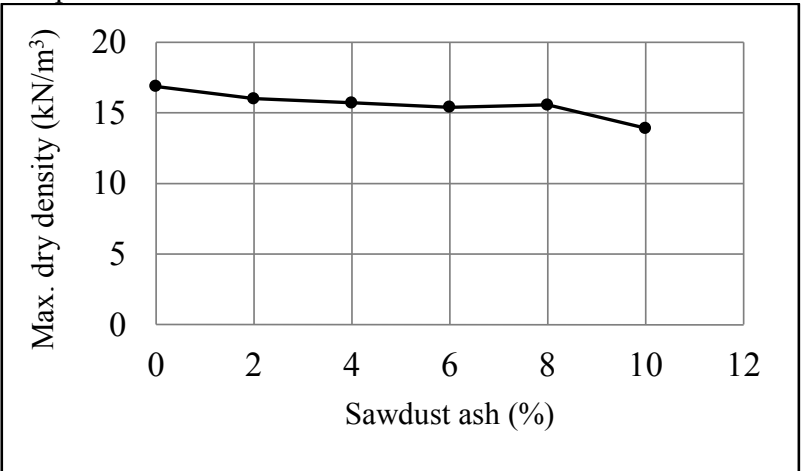


Fig. 7. Relation of maximum dry density (MDD) with added sawdust ash.

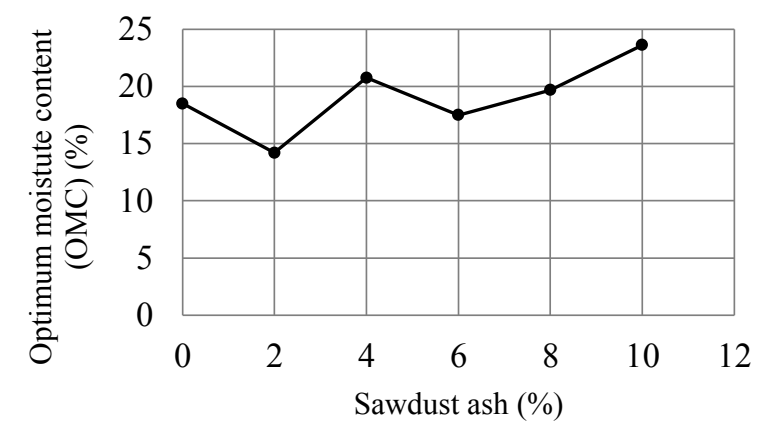

Fig. 8. Relation of optimum moisture content (OMC) with added sawdust ash.

The stress-strain curve of unconfined compressive strength (UCS) (Fig. 9) showed sharp increase in unconfined compressive strength $\left(\mathrm{q}_{\mathrm{u}}\right)$ and in turn its undrained shear strength $\left(c_{u}\right)$ with increasing SDA content to $4 \%$ by more than 4 times $\left(169.2 \mathrm{kN} / \mathrm{m}^{2}\right)$ of the natural soil $\left(39.2 \mathrm{kN} / \mathrm{m}^{2}\right)$. By examining stress-strain curves, it is well demonstrated that the addition of SDA (particularly 4\%) modify the soil deformation behavior characteristics in terms of brittleness or ductility by increasing the brittleness behavior of the treated soil and its stiffness which is related to strain softening. While Figure 10 displays the relation of UCS with percent of added sawdust ash. The increase in USC values is due to pozzolanic reactions of SDA. Thus according to Das (2000) [21], the consistency of the natural untreated soil which was very soft clay $\left(<25 \mathrm{kN} / \mathrm{m}^{2}\right)$, and after SDA addition ranges between medium soft $\left(50-100 \mathrm{kN} / \mathrm{m}^{2}\right)$ at $4 \%$ SDA to soft clay $\left(<50 \mathrm{kN} / \mathrm{m}^{2}\right)$ for the rest percentages, which is an improvement compared to the untreated soil. It is worth mentioning that almost the same results are obtained for untreated soil and that treated with $2 \%$ SDA.

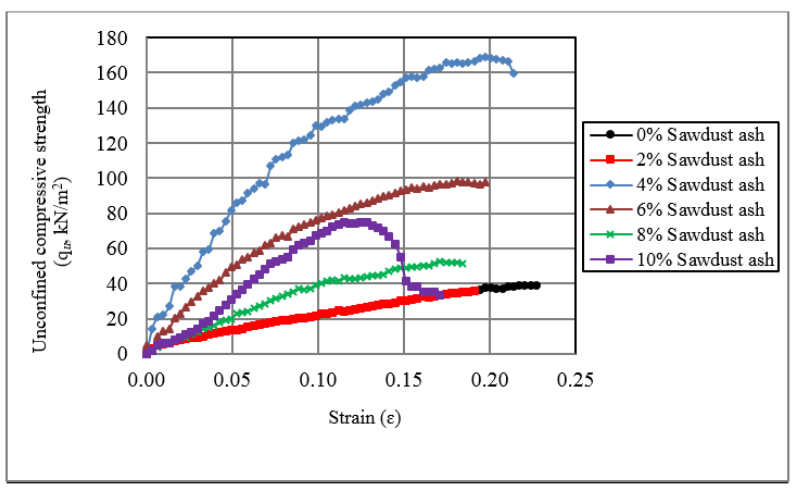

Fig. 9. Stress-strain relation of unconfined compression test for treated and untreated soil.

The effect of the SDA addition on soil compressibility is presented in consolidation curves shown in Figure 11. The relation between compressibility coefficients $\left(C_{c}\right.$ and $\left.C_{r}\right)$ with percent added of sawdust ash illustrates that the addition of ashes improved the soft clayey soil by reducing such coefficients particularly compression index, $C_{c}$, with no noticeable effect in swelling index, $C_{r}$. As an overall, it can be seen from Figure 12 that the minimum compressibility coefficients were obtained with the addition of $2 \%$ ash where $C_{c}=0.12$ and $C_{r}=0.02$.

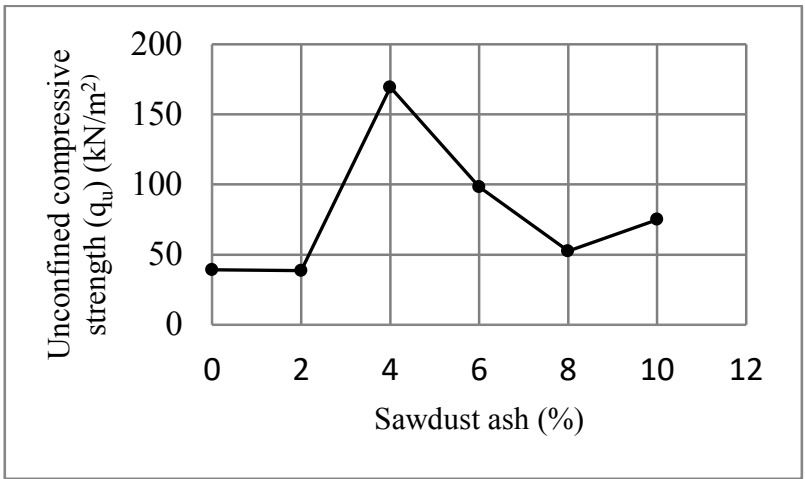

Fig. 10. Relation of undrained shear strength (cu) with added sawdust ash.

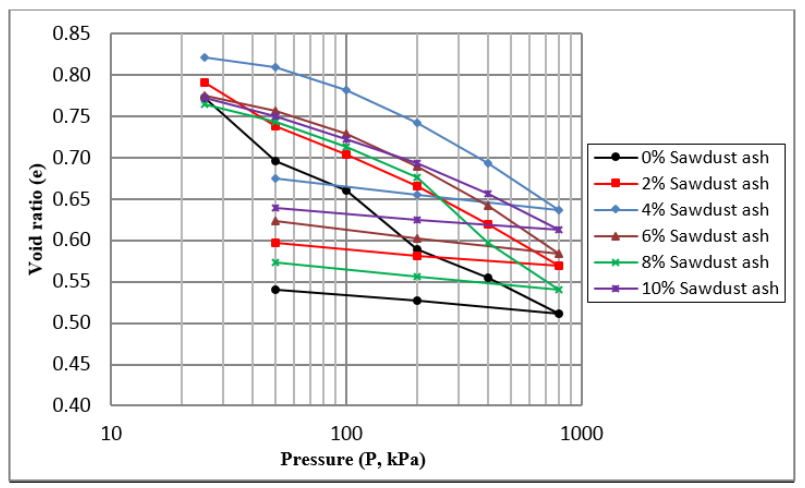

Fig. 11. e-log p relation for untreated and treated soils.

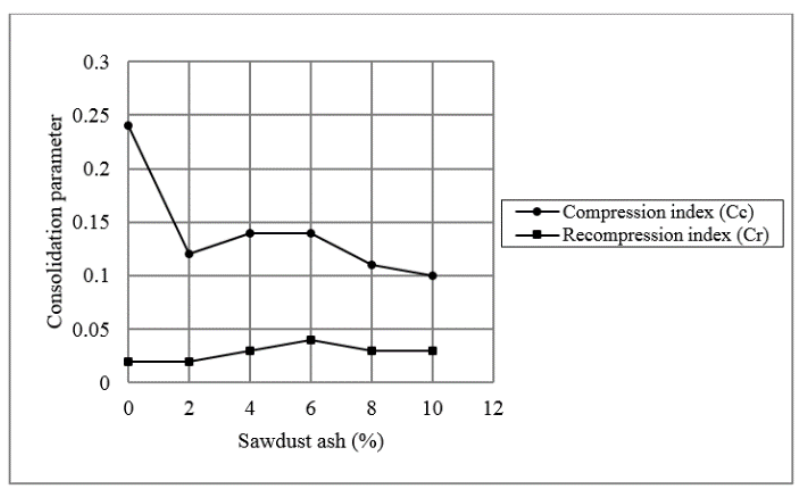

Fig. 12. Relation of consolidation parameters $(\mathrm{Cc}$ and $\mathrm{Cr})$ with added sawdust ash.

Concerning the California bearing ratio (CBR) tests, although the effect of SDA content on CBR of soil was not tested for all samples (just 0,4 and 10\% SDA addition), but it is important to have an estimate about it. The decrease in CBR in the tested proportions may be due to that such ashes could not be mobilized for the reaction which consequently occupies spaces within the sample. This will reduce the bonds in the soil-ash mixture, so low strength displayed by the SDA addition. 
However, according Asphalt Institute (1962) [22], the natural soil sample has $\mathrm{CBR}=16 \%$ which is considered to be a good sub-grade material, and the stabilized soils (with 4 and $10 \%$ ash content) resulted in low CBR values (1.6-1.2\%) which can be used as sub-base. This decrease in CBR values suggests that the soil samples become weaker indicating that SDA made treated soil high-plastic subbase materials. In general, the higher the plasticity Index, the lower in CBR value. Hence, general rating as sub-grade according to AASHTO (1986) [23] is fair to poor materials.

To summarize, it can be stated that the SDA additives can increase, to some extent, the strength and stability of the soft clay soil in the study area. Thus, both the treated and untreated soil samples are generally regarded as fair to poor for subgrade materials. The additives have adverse effects on the property of soil indices by increase in LL and PI which revealed the increase in fine particles (i.e. clay content) that make the soil less suitable (i.e. no enhancement) for construction purpose.

\section{Conclusions}

Based on the extensive tests conducted and results discussion, the following conclusions can be drawn:

1. Since, the average liquid limits of natural clayey soil samples are higher than $40 \%$, therefore soil under consideration is not suitable for road construction unless it is stabilized.

2. The SDA additive has an adverse effect on the property of soil indices by increasing LL and PI which implied by the increasing clay content.

3. With regard to the influence of SDA on density and compaction, test results show that SDA reduces the compacted dry density and increases the optimum moisture content of soft clay soils.

4. The mixture of SDA with soft clay soils improves the mechanical properties of the soil, as expressed by a reduction in the compression coefficients $\left(C_{c}\right.$ and $\left.C_{r}\right)$ and increasing the undrained shear strength $c_{u}$.

5. The stabilized soils (with 4 and 10\%) resulted in low CBR values (1-2) \% which can be used as sub-base material and fair to poor for subgrade materials.

6. In general, the optimum percentage of the SDA for improvement in the strength characteristic of the soil samples is $4-6 \%$.

7. The SDA can be considered as a cheap and acceptable stabilizing agent in road construction for improving most of the geotechnical properties of the soft clayey soil.

\section{References}

1. H.H. Karim, Z.W. Samueel, S.F. Ahmed, Proceedings of the $2^{\text {nd }}$ international conference of buildings, construction and environmental engineering, American University of Beirut (BCEE2), 17-18 Oct., 2015, Geotechnical Engineering Part, 117-121 (2015)
2. K.N.M. Yusof, L.C. Lun, P.P. Guan, S.A.A. Tajuddin, Technology and innovation for sustainable development conference (TISD2006), Faculty of Engineering, Khon Kaen University, Thailand, January (2006)

3. O.O. Amu, A.R. Origbemide, E.O. Saseun, Res J Appl Sci Eng Tech 2, 543-546 (2010)

4. O.O. Amu, O.S. Owokade, O.I. Shitan, Int J Eng Tech 3, 87-94 (2011)

5. H.H. Karim, Z.W. Samueel, M.S. Mohammed, Eng Tech J 34, Part (A), 1047-1057 (2016)

6. P.P Dahale, P.B. Nagarnaik, A.R. Gajbhiye, El J Geotech Eng 17, 2443-2461 (2012)

7. W.A. Butt, K. Gupta, J.N. Jha, Geo-Eng 7, 2-9 (2016)

8. A. Woode, D.K. Amoah, D. Nartey, D. Misefah, D. F.A. Nai, R.A. Nsoh, N.I. Addae, Civ Environ Res 6, 60-65 (2014)

9. ASTM D 2487-2000, Standard practice for classification of soils for engineering purposes (Unified Soil Classification System), (ASTM International, West Conshohocken, PA, United States, 2000)

10. S. Chowdhury, M. Mishra, O. Suganya, Ain Shams Eng J 6, 429-437 (2015)

11. ASTM D 854-2002, Standard test methods for specific gravity of soil solids by water Pycnometer, (ASTM International, West Conshohocken, PA, United States, 2002)

12. ASTM D 4318-2000, Standard test methods for liquid limit, plastic limit, and plasticity index of soils, (ASTM International, West Conshohocken, PA, United States, 2000)

13. ASTM D 1557-2000, Standard test methods for laboratory compaction characteristics of soil using modified effort $\left(56,000 \mathrm{ft}-\mathrm{lbf} / \mathrm{ft}^{3}\left(2,700 \mathrm{kN}-\mathrm{m} / \mathrm{m}^{3}\right)\right)$, (ASTM International, West Conshohocken, PA, United States, 2000)

14. ASTM D 2166-2000, Standard test method for unconfined compressive strength of cohesive soil, (ASTM International, West Conshohocken, PA, United States, 2000)

15. ASTM D 1883-2002, Standard test method for CBR (California Bearing Ratio) of laboratory-compacted soils, (ASTM International, West Conshohocken, PA, United States, 2002)

16. ASTM D 2435-1996, Standard test method for onedimensional consolidation properties of soils, (ASTM International, West Conshohocken, PA, United States, 1996)

17. A.E. Adetoro, O.S. Faluyi, Int J Sci Res in Knowledge 3, 288-296 (2015)

18. American Association of State Highway and Transportation Officials (AASHTO), Standard specification for transportation materials and methods of sampling and testing (14th ed.), (USA: Washington DC, AASHTO, 1986)

19. G. Sarkar, M.R. Islam, M. Alamgir, M. Rokonuzzaman, Int J Adv Struct Geotech Eng 01, 42-49 (2012) 
20. T. Henry, T. Ogunribido, Environ Res Eng Manag 2, 29-33 (2012)

21. B.M. Das, Fundamental of geotechnical engineering, (Thomson Learning, USA, 2000)

22. Asphalt Institute, The asphalt handbook, Mary Land USA, 176P (1962)

23. R. Whitlow, Basic soil mechanics, (Addison Wesley Longman Limited, 1995) 